\title{
The New Dionysos in Vase Painting
}

Shortly after the completion of the Parthenon, striking innovations could be discerned in the way Dionysos appeared in vase painting: the dignified mature bearded man was increasingly replaced by a youthful figure, sitting or reclining in a relaxed manner. It is evident that the Dionysos 'who unfastens' in the east pediment of the Parthenon is behind the changes. It is instructive to have a look at some examples.

In the work of the Washing Painter, active from just after 440 until around $410 \mathrm{BC}$, Dionysos is completely absent and only six of his more than fifty pelikai have satyrs and maenads. ${ }^{1}$ This may be partly explained from the fact that he mainly produced vases-loutrophoroi, lebetes, pelikai-that were meant to be used by women at special occasions, such as weddings; their imagery was therefore rather uniform and dictated by tradition.

From the perspective of Dionysiac iconography, the Dinos Painter is the most important painter at this stage. He is said to have been a pupil of the Kleophon Painter, whose style he continues "in a less solemn and a sweeter form", as Beazley puts it. ${ }^{2}$ His work may be dated between 430 and 400 BC; it has its acme around $410 .^{3} \mathrm{He}$ seems to have been particularly interested in Dionysiac subjects.

His famous stamnos in Naples still shows the strong stylistic influence of the Parthenon, even though it is by far the youngest of the series depicting a domestic ritual with a pillar idol of Dionsyos, and may therefore be a nostalgic revival of the motif (Figure 98). ${ }^{4}$ The scene with the woman ladling the wine from the stamnos is here explicitly linked to the procession of women on the other side of the vase: the woman beating the tympanon to the right of the idol is looking back towards the approaching dancer carrying torches, who in turn is followed by the four women on the reverse. All women are wearing the sleeveless chiton, some with an animal skin over it. Only the last woman in the procession is wrapped in her himation, which creates the impression that she is the one to be led to the ritual. The veiled women on the reverse sides of the two

1 ARV 1130. 144-149. For the dating see Isler-Kerényi 1973, $28 \mathrm{f}$.

2 ARV 1151.

3 McPhee 1973, 1; Halm-Tisserant 1988, 8 and 12.

4 Naples 2419: Addenda 336 (1151.2); BA 215254; Frontisi-Ducroux 1991, 84 f., figs 19 and 20; HalmTisserant 1988, 7. See also above Chapter 6. 


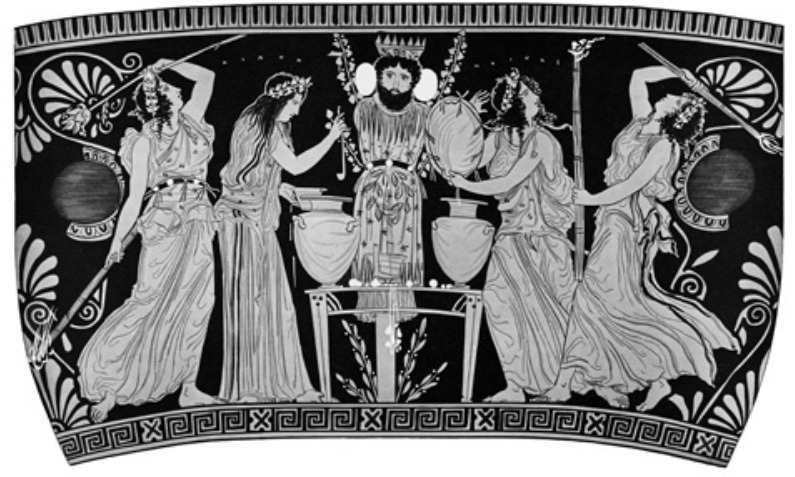

$a$

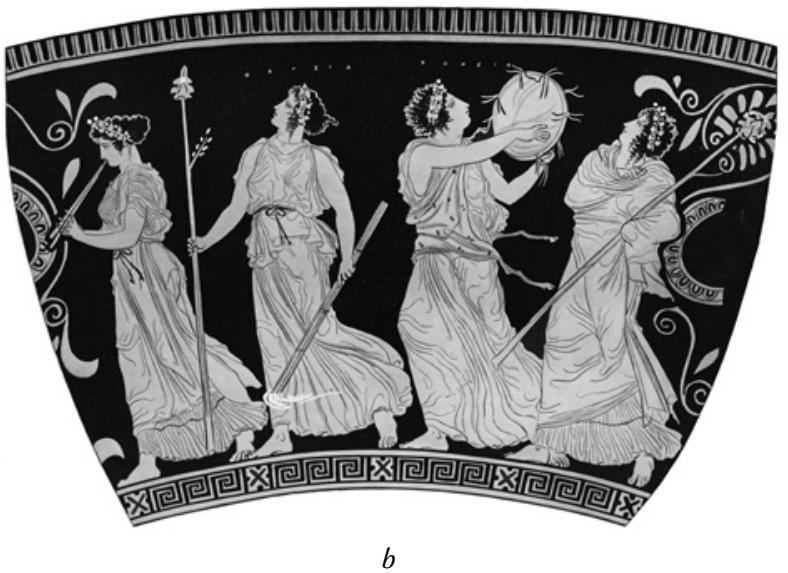

FIgure 98 Stamnos, Dinos Painter, Naples, Museo Archeologico Nazionale 2419.

a. side A (FR pl. 36$)$.

b. side $B$ (FR pl. 37 below).

stamnoi by the Eupolis Painter which also belong to the series are very similar. ${ }^{5}$ Are they also waiting to be introduced? Is the anonymous bearded man in a himation, who may be seen in one of the images, a member of the family? The four names added on the Naples stamnos-Aione, Mainas, Thaleia, Choreiasound mythological, but in view of the iconography the ritual depicted most likely reflects human circumstances. ${ }^{6}$

5 Frontisi-Ducroux 1991, 157, figs 92 and 93.

6 See above Chapter 6 . We will return to the issue of inscribed names at the end of this chapter. 

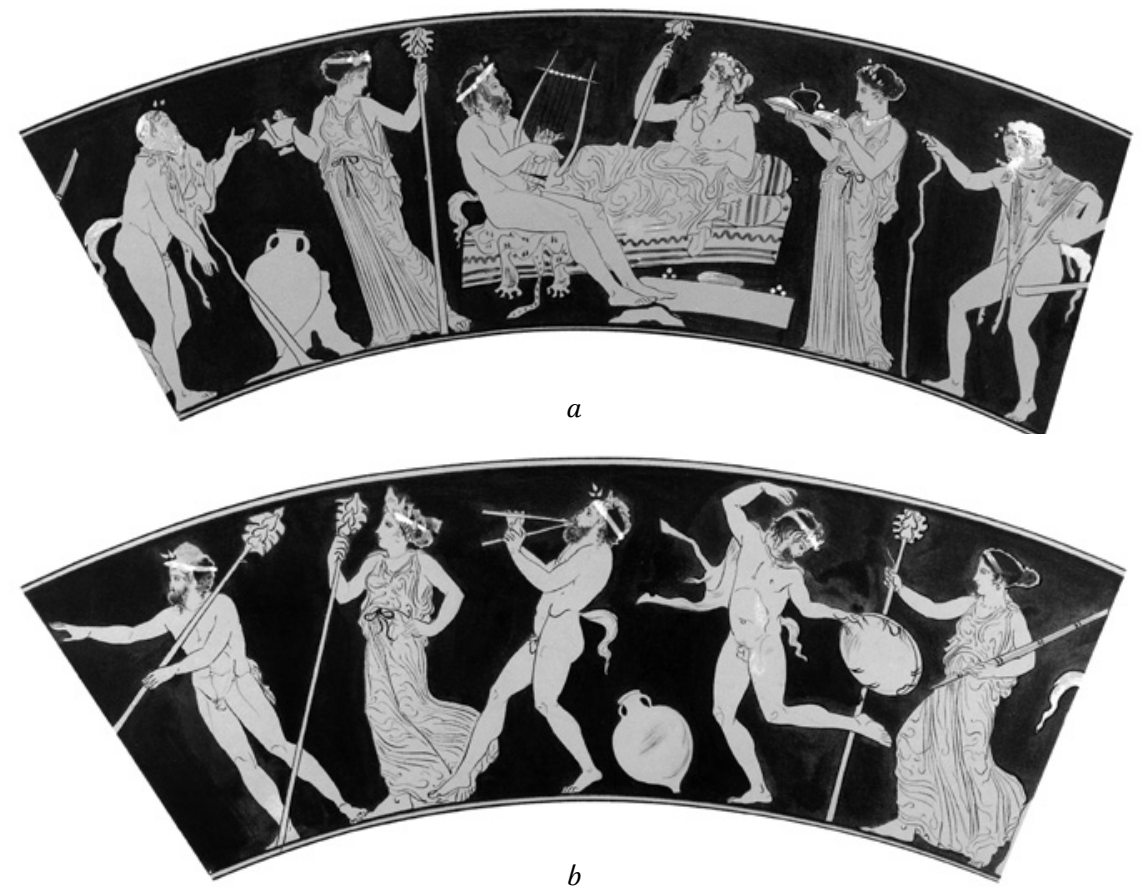

FIGU Re 99 Dinos, Dinos Painter, Berlin, Staatliche Antikensammlungen, Preussischer Kulturbesitz F 2402 (Furtwängler 1883-87, pl. 56-57).

a. side A: Dionysos.

b. side B: thiasos.

Another work by this painter that is of importance for our discussion is the eponymous dinos, dated around 420 ; the best-known of the four dinoi attributed to him. ${ }^{7}$ No less than three of these were found in Athens and several other vases by the Dinos Painter were also found here. We may therefore presume these works present the Athenian perspective on Dionysos and his rituals. The dinos in Berlin shows one of the earliest examples of the young Dionysos as a symposiast - a motif that would be among the most common ones also in Apulian vase painting. ${ }^{8}$ The amphora placed against a rock to the left of the main scene must be a reference to unspoiled nature; the ambivalent characterization of the locale seems intentional. In addition, it is remarkable that the satyrs who are present, are of different ages. The one playing the lyra who sits on Dionysos' bed, and the dancing ones on the reverse, are clearly

7 ARV $115^{2.3}-6$.

8 Berlin F 2402: Addenda 336 (1152.3); BA 215255. Similarly Sabetai 2011, 139. 
younger than the white-haired one who, leaning on his stick, approaches on the right. A woman stands in front of him, turned towards the left. She solemnly carries a basket with, probably, loaves of bread, and — as on the chous from Trachones, discussed above-a large cluster of grapes. ${ }^{9}$ She will probably put these on the podium-like structure in front of Dionysos' couch. On the other side of the god another woman is ready with the kantharos she perhaps just filled from the amphora: Dionysos is comfortably settled and given a warm reception (Figure 99).

A recently published small calyx krater in Athens, attributed to the Dinos Painter, shows the Parthenon type, albeit with a himation draped over the lower body. He is, however, holding kantharos and thyrsos in the appropriate hands. ${ }^{10}$ As in the Berlin dinos, Dionysos reclines on a couch. Instead of a satyr, Ariadne sits at its foot, a wreath in her hands as in the Kodros Painter's cup, discussed above." Between the two, Eros can be seen, flying towards Ariadne. Dionysos brings the kantharos to his lips, his thyrsos is decorated with a ribbon. In the foreground stand a gilded volute krater as well as a podium, highlighted in white, with offerings. Above right a bacchante beats the tympanon, and another, wearing a colorful ritual robe, is bringing further offerings. A boylike satyr is approaching from the left with drinking horn and oinochoe. On the reverse, two women are walking towards the right - the one in front carries a thyrsos, the other one a tympanon. They seem to be moving towards the scene on the main side of the krater and the altar visible above the handle between the two images. In addition there is an elderly satyr in a himation. He is dancing along while looking back with a greeting gesture. Behind him, above the other handle, we can see an open door. Does this refer to the thalamos, where the wedding of Dionysos and Ariadne takes place, or to a sanctuary of the god? Perhaps the door is supposed to represent an ideal transition from inside to outside world and vice versa, or even what we might call the Final Transition. ${ }^{12}$ The two satyrs of different ages, and especially the one in the himation, indicate an event which, like the processions discussed earlier, takes us from the human here and now to an imagined world populated by immortal beings-a higher world for humans to look forward to. ${ }^{13}$

\footnotetext{
$9 \quad$ See above Chapter 6, note 87 .

$10 \quad$ Sabetai 2011.

11 London E 82 (1847.9-9.6): see above Chapter 5, note 42.

12 Sabetai 2011, $15^{2} \mathrm{f}$. The motif of the (sometimes half-open) door on sarcophagi from the Imperial period very likely refers to this idea of Final Transition. See for instance: Koch/ Sichtermann 1982, figs 258, 290, 291, 523, 529, and 535 .

13 See above Chapter 6.
} 

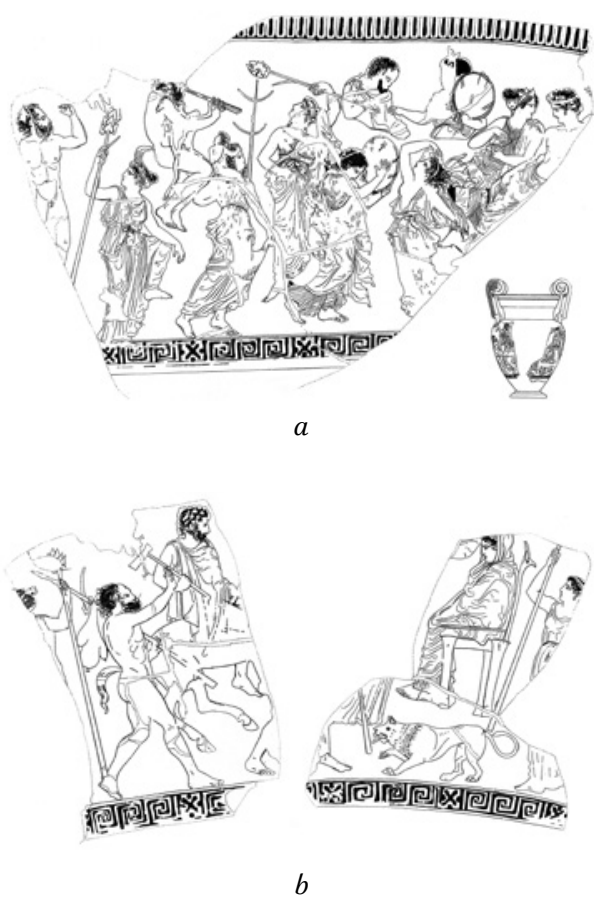

Figure 100 Volute krater, Dinos Painter, Bologna, Museo Civico Archeologico 283 (AD I, pl. 36).

a. side A: Dionysos and Ariadne watching the thiasos.

b. side B: Hephaistos riding towards Hera.

Of prime importance among the works of the Dinos Painter known to us is a somewhat younger volute krater from North-Etruscan Bologna, which is, unfortunately, badly preserved (Figure 100). ${ }^{14}$ It showed an exceptionally lively thiasos of women and satyrs accompanying Hephaistos riding his mule. He is on his way to Hera, who is stuck on the right. She sits like a mourner wrapped in her himation and is guarded by an aggressively roaring lioness. On the other side of the vase, a youthful seated Dionysos, half naked and relaxed, is watching the thiasos in the loving company of Ariadne. ${ }^{15}$ The whole scene, especially the women dancing ecstatically to the music of flute and tympanon, strongly reminds us of a vase which was discussed in the previous chapter: the more or

\footnotetext{
14 Bologna 283: Addenda 336 (1151.1); BA 215253. For the motif of the return and Hera stuck in her seat, see Halm-Tisserant 1986, 18-21.

15 The same motif can be found on a fragment of a bell krater from Phanagoria in the Crimea, attributed to the Dinos Painter: BA 1012120.
} 
less contemporaneous volute krater from Spina decorated by the Curti Painter, possibly for an Etruscan client. ${ }^{16}$ Here, however, the male participants are satyrs (one of them seems to be wearing a himation) and there are no snakes. One of the dancing women is carrying her small child on the shoulder: this representation of what must be a woman with mother status, a gynè, is unique. On the extreme left a satyr looking towards the right is closing off the scene; he lifts his left hand in what is probably the skopeuma gesture. ${ }^{17}$ This could indicate that we are witnessing an epiphany of the divine couple. In this juxtaposition of a mythological scene and a thiasos resounding with music, it remains unclear whether the latter takes place among human beings or in a blissful other world. What is most striking when one compares this version of the return of Hephaistos with the earlier depictions of the theme is the difference in mood between the anxiety of the Hera side - with the intimidating lioness providing an ominous touch - and the euphoric happiness of the Dionysos side. There even seems to be an intentional pictorial contrast: on the one side Hera is waiting to be set free by the son she rejected, while on the other a bacchante and her little son are joyfully taking part in a euphoric thiasos. In any case, here too, Dionysos is the god of peace, who unfastens, unfetters.

A Dionysos figure that is evidently inspired by the rendering of the god in the east pediment of the Parthenon is the one on the calyx krater in Vienna (Figure 101). ${ }^{18} \mathrm{He}$ dominates the main side of the vase, and is surrounded by women in colorful ritual robes (Dione and Opora) who bring gifts-among which two large clusters of grapes-, and by satyrs (of whom the one on the right is named Komos). As on the dinos, a seated satyr plays the lyra. To the right of Dionysos' head we see Eros who crowns the god with a wreath. The figure of Eros is highlighted in white, as is the podium-like structure in the foreground, which gives both elements additional significance. A panther's cub near the podium seems eager to play with the satyr-musician. From now on, we increasingly see the relaxing Dionysos in the company of a tame panther. Perhaps it stands for a subdued Asia; in this way the presence of the animal would be enough to evoke the idea of a utopian peace. On the reverse a satyr is moving towards a fleeing maenad with alacrity. To the left, a dancing maenad is turning away. Her gesture is apparently meant to express her disapproval of the satyr above the right handle who, with obvious intentions, is approaching an unsuspecting woman (Oinanthe) watching Dionysos. Above the left handle, a woman (Eirene) is sitting on the left; a satyr (Hedyoinos) who is lying in the

\footnotetext{
16 Ferrara 2897: see above Chapter 6, note 143.

17 CVA Bologna 4, pl. 69.6 with text p. 11 (G. Bermond Montanari).

18 Vienna 1024: Addenda 336 (1152.8); BA 215261.
} 


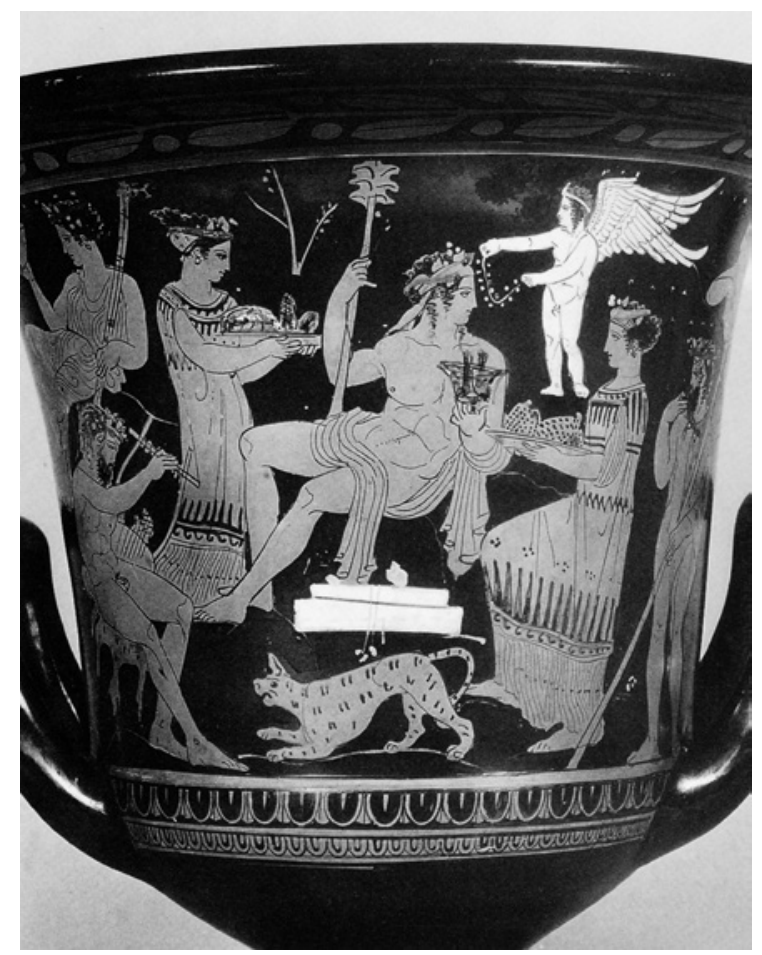

FIGU RE 101 Calyx krater, Dinos Painter, Kunsthistorisches Museum, Vienna 1024, side A (cVA Kunsthistorisches Museum, Vienna 3, pl. 105.2).

field in a half-reclining attitude turns towards the god, a kantharos in his right hand. 19

Images such as this, often with Ariadne next to Dionysos, were the Athenian painters' preferred imagery from this time onward until far into the 4 th century. A comparison between the Dinos Painter's return of Hephaistos and the not much earlier version by the Kleophon Painter convincingly shows the profound changes in the Dionysiac climate in Athens around 420. One only has to remember the rather solemn procession-like trains with torches and thyrsoi presented by the Phiale Painter or on the stamnos by the Dinos Painter and it becomes evident that the ritual event has shifted from the immediate surroundings of the viewer to a seemingly timeless, blissful, distant world, standing out as if on a stage.

A contemporary of the Dinos Painter whose oeuvre contains several interesting Dionysiac images, is the Kadmos Painter. He was active during the same

19 Smith, 2007, 169. 


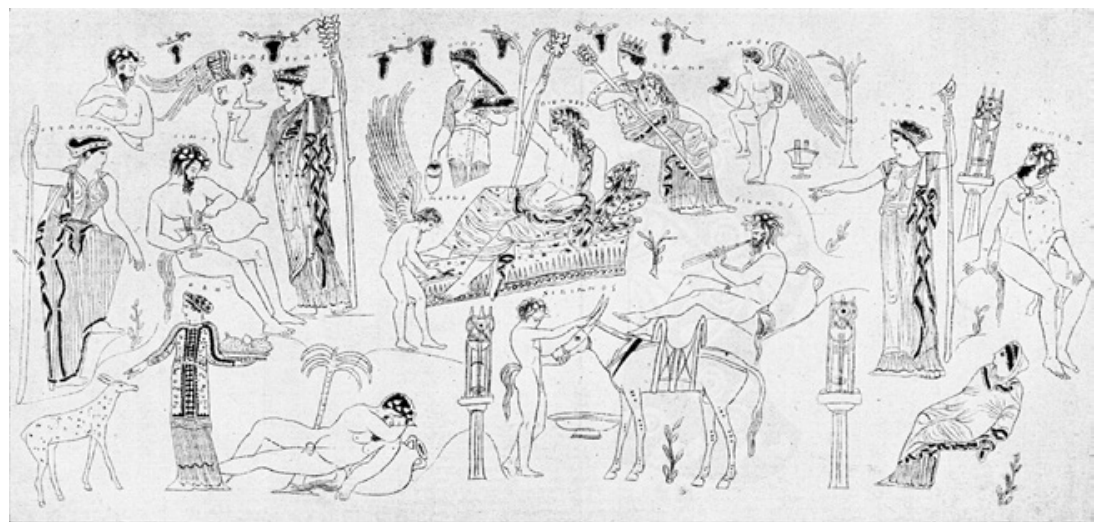

FIGURE 102

Volute krater, Kadmos Painter, Ruvo, Museo Jatta 1093, scroll showing side A between parts of side B (FR Text II, 329, fig. 107).

decades, but, at least as far as his numerous bell kraters are concerned, not at the same artistic level. His volute and calyx kraters as well as his amphorae with twisted handles, however, distinguish themselves by their original subject matter and their careful execution. ${ }^{20}$ Among these we find several remarkable representations of Dionysos.

Most richly decorated is the volute krater found in Ruvo, in the Apulian inland. ${ }^{21}$ This location provides an indication of one of the possible routes via which Dionysiac iconography from Athens found its way to the workshops of Southern Italy.22 The krater has four images: two small ones on the neck and two larger fields on the belly. One side is completely dedicated to the story of Marsyas, the musician-satyr. On the neck Marsyas plays the aulos for Apollo in the presence of a dancing satyr, a woman with two torches, and Hermes. The center of the image on the belly is dominated by Marsyas (the name is given), who is represented as an elderly satyr playing the kithara, and Athena, who is listening. Apollo is sitting in a relaxed attitude to the right of Athena; Artemis is leaning on his shoulder. Several other figures surround the main protagonists. Below on the left a bacchante holding a thyrsos is conversing with a young satyr; above them we see a partly veiled goddess (Hera perhaps) with

20 See above Chapter 5, note 116. For the dating of the Kadmos Painter, see McPhee 173, 51. For the Kadmos Painter see in addition Tiverios 2011.

21 Ruvo 1093: Addenda 340 (1184.1); BA 215689; Sichtermann 1966, K 10, 20 f., pls. 12-17; Shapiro 1993, 235, no. 22; Borg 2002, 220; Lissarrague 2013, 161 f., figs 134-135 (the dating seems too early).

Similarly Paleothodoros 2011, 140 and Tiverios 2011, 176. 
a young woman whose name, Hebe, is given; above right are Nike or Iris with Hermes. A tripod is standing on a pedestal in the foreground, a little higher a palm tree may be seen, in front of Artemis a grazing fawn. Evidently, we find ourselves in a sanctuary of Apollo, where there is no indication whatsoever of the further tragic developments. Rather, the atmosphere is one of peace and relaxation.

The neck image on the other side shows pieces of meat roasting on a spit over the altar with anonymous boys, mature men, and women in attendance. The main image is dominated by a youthful Dionysos, whose name is inscribed. He is reclining on a richly decorated couch and wears an ivy wreath on his head. In his left hand he holds the thyrsos (Figure 102). The winged boy Himeros is putting sandals on Dionysos feet. The god is surrounded by women carrying various objects: Eudia is on his left; Opora above has a basket with large bunches of grapes. ${ }^{23}$ A matron in festive dress sits on the right in a somewhat elevated place. She is the only one to wear a halo-like diadem; this is in accordance with her name, Thyone, the name given to Semele after her death. In addition we see Pothos (who looks like Eros) with a bunch of grapes, as well as satyrs engaged in various activities ( from left to right Simos, Sikinnos, Seilenos and Oinopion). One of them seems to be trying to lead a mule. Next to Dionysos a large vine carrying ripe grapes has sprouted, and here, too, there are tripods and palm trees. How do these two scenes relate? Is this the same locale, as the presence of bacchante and satyrs on the Apollo side suggests? In any case, both sides show the relaxed, idyllic atmosphere we also found on the dinos and the calyx krater by the Dinos Painter.

On one of the Kadmos Painter's calyx kraters we again see Apollo and Marsyas in the company of other gods; the other side has the encounter of Dionysos with Ariadne discussed above. ${ }^{24}$ In contrast to earlier versions, in which the encounter was more like a pursuit, the mood here is one of respectful solemnity.

The other calyx krater was found in Kerch on the Black Sea. ${ }^{25}$ One side has a detailed depiction of the Judgment of Paris. In the center we see Paris seated in the foreground. He is wearing the multi-colored oriental trousers in which he is first portrayed around $430 \mathrm{BC}$ - this will be further discussed in the next chapter. He is surrounded by Hermes, Athena, Hera, and Aphrodite. In the

23 Other women are named Eudaimonia, Hebe and Oreias, see fig. 102.

24 Syracuse 17427: see above Chapter 5, note 116.

25 St. Petersburg 0.28 (St. 1807): Addenda 341 (1185.7); BA 215695; LIMC III, Eris 7, and VII, Paridis Iudicum 48 (side A) and LIMC II, Apollo 768a (side B); McPhee 1973, 95-99; Shapiro 1993, 233, no. 15 . 


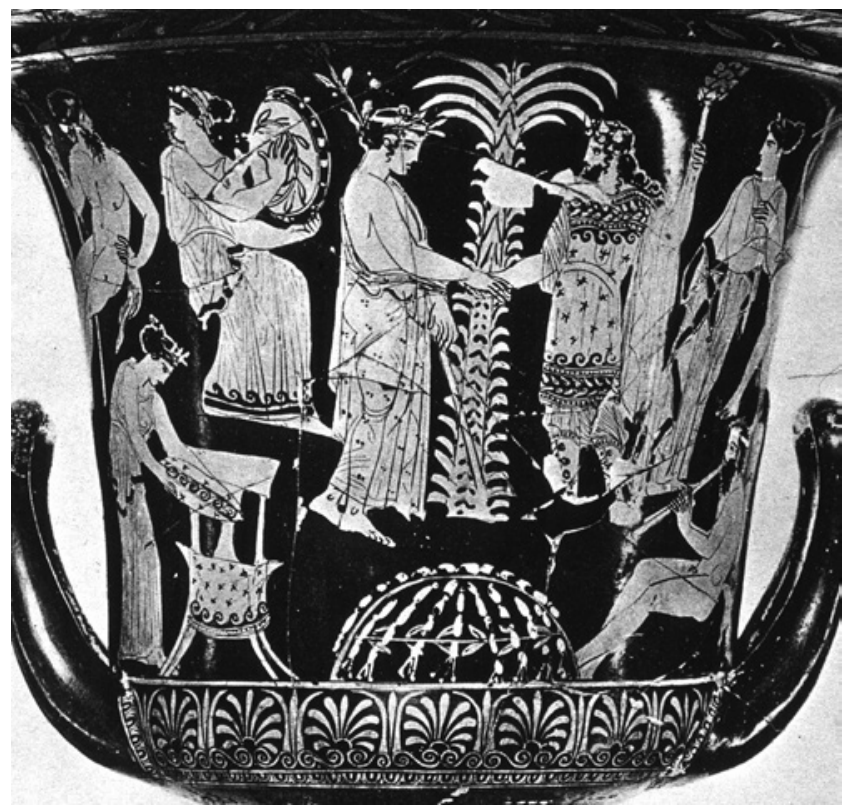

FI U URE 103 Calyx krater, Kadmos Painter, St. Petersburg, State Hermitage Museum 0.28 (St. 1807), side B (old photograph from the Archäologisches Institut der Universität Zürich).

upper field, framed on the left and right by the chariots of Eos and Selene, we see two women directly above Paris. Their names are given: Themis is leaning against Eris, who is wearing multi-colored robes. This prominently-placed pair, until that time not found in representations of the Judgment of Paris, and the presence of the celestial bodies of Day and Night, underline the significance of the event for the history of the world. As we all know, the Judgment of Paris had been the cause of the Trojan War, Greece's ill-fated confrontation with the power of Asia, as Herodotus had argued some time before the creation of this image. ${ }^{26}$ Themis, the goddess of lawful order, leaning against Eris, the goddess of strife, means that the war was justified and, in this way, was a condition for the current order.

The image on the reverse side is unique. In the center we see the omphalos, which symbolizes Delphi, with immediately above it a large palm tree. The latter stands for Delos, the other major sanctuary of Apollo. ${ }^{27}$ The main event takes place in front of the palm tree: Apollo, dressed like a young citizen, with a

\footnotetext{
26 Hdt I, 1. 4.

27 Simon 1998a, 457. The palm tree, however, also belongs to Artemis, see Torelli 2002.
} 
laurel branch in his left hand and a laurel wreath in his hair, shakes the hand of Dionysos who comes from the right. He wears an ivy wreath in his long hair and is bearded and therefore clearly older than Apollo. Over his chiton he wears the multi-colored ependytis and he has boots on his feet. We must therefore conclude that he has traveled far, from the east perhaps. Dionysiac women and satyrs liven up the scene with the music of tympanon and aulos. In the foreground on the left, a woman is putting a colorful cushion in an armchair. This is probably where the newly-arrived god will take his seat. The whole scene radiates quiet solemnity (Figure 103).

We do not know what myth or real event the scene refers to. Nevertheless, it acquires meaning when we relate it to the image on the reverse which refers to a war that was inevitable - the war that, for the original viewers, ended the era of the heroes and inaugurated that of human beings. For did one not calculate the time according to the generations that had passed since the ancestors of the great families, the heroes of the Trojan War? The goddess of strife and the handshake, a symbol of peace, are juxtaposed. The peace in question may be the one between Dionysos, who comes from afar, and Apollo, god of all the Greeks and also of the Athenians, who is shown in his sanctuary, the place that, with the prominently presented omphalos, was seen by the Greeks as the center of the earth. ${ }^{28}$ This Dionysos, however, is no more an Asian deity than the Dionysos in Euripides' Bakchai, who around the same time speaks of himself as returning to Thebes from Asia: the difference between his costume and that of Paris already make this clear. ${ }^{29}$ Nevertheless, Dionysos represents the world beyond Greece. In the words of Henk Versnel: "Dionysos is a cosmopolitan god who demands reverence by all people all over the world."30 It may be for this reason that he is depicted as being older than Apollo, albeit clearly not like a father figure. A chair is prepared for him, like in Athens during the Anthesteria, indicating that he should stay. ${ }^{31}$ An evocation of peace such as this one eminently suits the later stages of the Peloponnesian War. And it is particularly apt for the place where the vase was found: Kerch on the northern shore of the Black Sea, that is, the northern frontier of what was then for the Greeks the known world. It cannot be a coincidence that this location (with its new concept of a far-reaching Dionysos) is also the one where the hydria of two generations earlier was found which presented the dispute between Athena

\footnotetext{
28 Versnel 2011a, 506: quotation from Dem. 18.141 concerning Apollo: patroos esti te polei.

29 E. Ba.1-19.

$30 \quad$ Versnel 1990, 164.

31 See above Chapter 6, p. 152.
} 
and Poseidon inspired by the west pediment of the Parthenon, discussed in the previous chapter. ${ }^{32}$

Thus we owe the Kadmos Painter three of the most original and therefore least accessible images of Dionysos. As far as Dionysos' outward appearance is concerned, it is striking that next to the youthful Dionysos inspired by the east pediment of the Parthenon on the volute krater, the mature spouse-type could also still be found in his sanctuaries. ${ }^{33}$ Finally, in the sanctuary of Apollo in Delphi we meet a very special exotic Dionysos who is neither young nor elderly. Evidently, the new Dionysos of the east pediment of the Parthenon had not come to replace the traditional Dionysos; it inaugurated his polymorphism, the variety of forms that would be the hallmark of Dionysiac imagery (including sculpture) from the 4 th century вС onward. ${ }^{34}$

In all three instances, Dionysos is either placed next to to Apollo or combined with him on the same vessel. As is demonstrated by, for instance, the work of the Shuvalov Painter (with more than twenty representations of Apollo) as well as that of the Pothos Painter and the Meidias Painter, in the years following the Plague of Athens Apollo was more in evidence than earlier or later: would he have been seen as the cause of the epidemic or as a healer? In any case, he was the embodiment of a longing for a moral code, justice, recognition of the divine order, which always seems more pregnant in times of crisis. ${ }^{35}$ Moreover, the juxtaposition of the two gods is in accordance with the fact that at the Parthenon Dionysos is presented as the brother of Apollo, i.e. as someone who complements Apollo. As far as monumental art is concerned, this perspective is continued in the decoration of the west pediment of the temple of Apollo in Delphi, created around 350 BC by an artist from Athens, where Dionysos appears as Kitharodos, a role associated with Apollo. ${ }^{36}$

The Kadmos Painter, the circle of Polygnotos, and the cups of the Kodros Painter present the relationship with Ariadne in a manner that is quite different from that of the somewhat earlier work of the Syleus, Harrow, Niobid and Lewis Painters. ${ }^{37}$ This is no longer a dramatic —and for Ariadne perhaps

\footnotetext{
32 St. Petersburg $\Pi_{1872.130}$ (КАв 6 а), see above Chapter 7 , note 94.

33 He is also depicted in this way, reclining with Herakles on the symposium couch, on the more modest pelike London 1956.2-17.1: ARV 1186.31; BA 215720.

34 Compare Plutarch, quoted by Massa $2006-2007,82 \mathrm{f}$.

35 Moret 1982, 134.

36 Croissant 2003, 85-87, pl. 34 .

37 Circle of Polygnotos: Tarquinia RC 4197 (see above Chapter 6, note 129) and Tübingen 5439 (see above Chapter 6, note 131); Kodros Painter: London E 82 (see above Chapter 5, note 42) and Würzburg H 4616 (491) (see above Chapter 6, note 135); earlier works: see above Chapter 5 , notes 104, 107, 114, and 119 .
} 
even traumatic — confrontation, but a marriage based on mutual agreement, a situation of joyful companionship. ${ }^{38}$ It is not a coincidence that Eros now seems part of the Dionysiac world, even in images where Ariadne is lacking. The winged child not only embodies Dionysos' erotic aura, but also, as Greifenhagen already pointed out, everything that comes into being and is, therefore, unknown. ${ }^{39}$ The presence of Eros speaks of a new era beginning with Dionysos, and now not just for the polis, but first and foremost for the individual beholder of the image. ${ }^{40}$

The Kodros Painter, one of the cup painters who were active just after the completion of the Parthenon, has already been discussed. ${ }^{41}$ Another prominent artistic personality of the time is the Eretria Painter, whose work may be dated between 440 and 415 BC. ${ }^{42}$ Apart from cups, he decorated a number of the smaller-size vase types. ${ }^{43}$ As far as cups are concerned, his Dionsyiac scenes, which, with images of athletes, belong to his most frequently represented subjects, consist of rather conventional depictions of the thiasos with satyrs and dancing women. In one instance, dated around 430-425, one of the outside images shows Dionysos riding a mule or a donkey amidst ecstatically moving satyrs. He is bearded, wears a short chiton and boots with tongues, and has a thyrsos in his right hand. ${ }^{44}$ There are, so far, no parallels for this image. On the reverse, we find a satyr, who sits somewhat precariously on his mount, accompanied by two comrades with torches. The inside image shows a satyr riding in side saddle. It is evident from black-figure iconography that a man riding a mule in a Dionysiac ambiance is not necessarily the mythological Hephaistos returning to the Olympus. ${ }^{45}$ It is quite possible that a carnivalesque ritual of this kind actually took place in 5 th-century Athens. In addition, I would like to mention another cup which has recently been attributed to the Calliope Painter, a somewhat older collaborator of the Eretria Painter. ${ }^{46}$ It shows satyrs in the citizen's himation: on both outside images they are engaged in quiet conversation with women carrying thyrsoi, in the inside image they are standing

38 Sabetai 2011, 146: "In general, the imagery of Dionysos' union with Ariadne after the mid5 th century вс conveys the idea of conjugal union." Greifenhagen 1957, 24; Isler-Kerényi 1984a, 385; Isler-Kerényi 2004b, 247.

40 As is the case with the east pediment of the Parthenon, see above Chapter 7 .

41 See above Chapter 5, p. 98.

42 Lezzi-Hafter 1988, 23.

43 Boardman 1989, 98.

44 London E 102: ARV 1253.70; вA 217008; Lezzi-Hafter 1988, 159 and 312, no. 15, pls. 10 and $53 \mathrm{c}$.

45 Isler-Kerényi 2004a, 48-51.

46 Ruvo 1442: ARV 1261.54; BA 217123; Lezzi-Hafter 1988, 323, no. 90, pl. 69. 


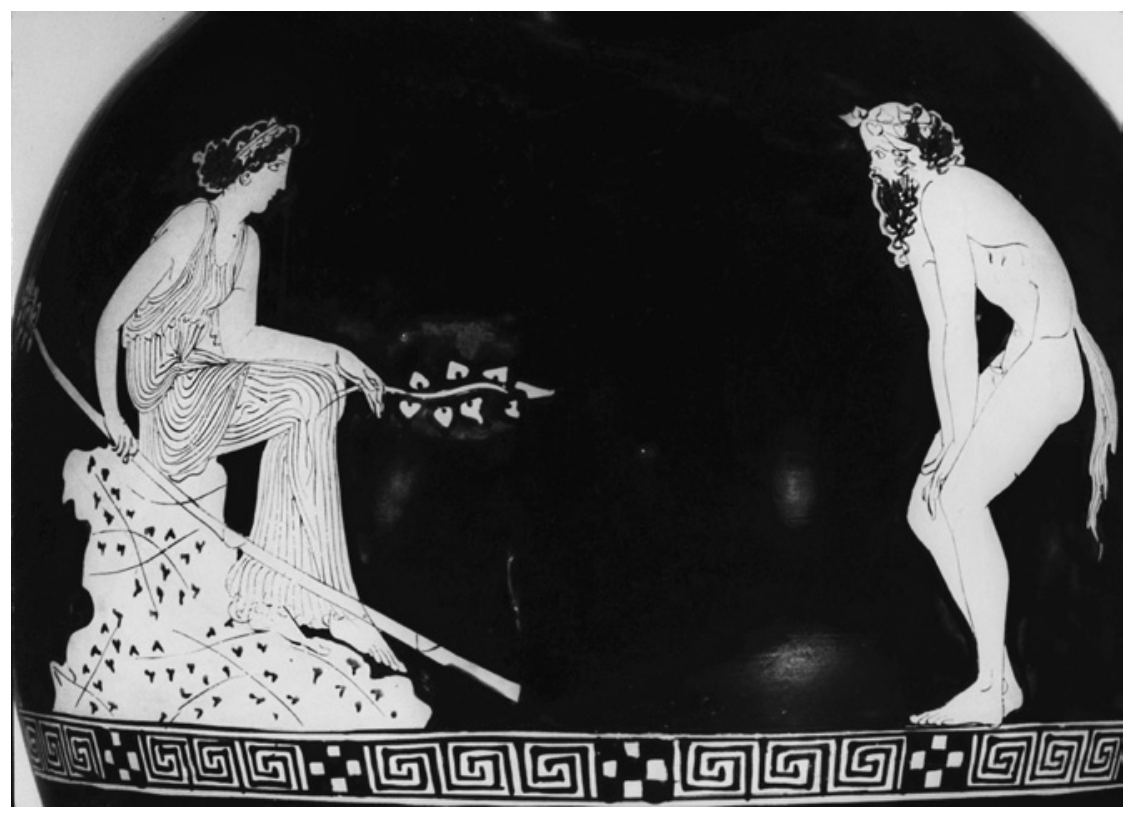

FIGURE 104

Chous, Eretria Painter, Basel, Antikenmuseum Basel und Sammlung Ludwig BS 407 (Lezzi-Hafter 1988, pl. 134).

next to an altar. This is not a thiasos situation, but just men and women meeting in a Dionysiac context.

The Eretria Painter's best work is perhaps his large chous. Especially attractive is the calm but suspenseful confrontation of a woman who, armed with a thyrsos, is sitting on a ivy-covered rock, with a satyr ready to jump (Figure 104). ${ }^{47}$ The chous showing a rather original version of the return of Hephaistos briefly discussed earlier, dates to the same period: the years between 430 and $425 .{ }^{48}$ The two gods, bearded and with ivy wreaths, together ride the same mule: Dionysos is in front with his kantharos, Hephaistos behind him with a smith's cap on his head and a pair of tongs in his left hand. With his right he salutes the satyr who walks in front of them. The spaciousness of the composition has turned the familiar boisterous train of earlier versions into a solemn event.

Scholarship has given special attention to three choes by the Eretria Painter excavated in Attica and in Athens, and another one of a slightly younger date

47 Basel bs 407: Addenda 354 (1249.12 bis); BA 275512; Lezzi-Hafter 1988, 338, no. 212, pl. 134; Schmidt 2005, 188, fig. 95 .

48 New York 08.258.22: see above Chapter 6, note 141; Lezzi-Hafter 1988, 339, no. 213, pl. 135; Schmidt 2005, 174, fig. 88; Smith 2007, 157 f.; Lissarrague 2013, 156, fig. 129. 
by the Meidias Painter who originally was one of his collaborators. ${ }^{49}$ The reason for this is that the ritual acts depicted on them can, on the basis of the image carrier, be associated with the Anthesteria. We already discussed the two choes with the swing in the center of the image and on the left the outsize klismos apparently meant for Dionysos. ${ }^{50}$ The other two choes have a threelegged table at the center of the image, with on it a liknon, a wide basket. On the oldest known of the two, a large Dionysos mask has been placed inside the liknon. ${ }^{51} \mathrm{~A}$ woman is solemnly approaching from the left with a kantharos in her hands, on the right a young woman with an ivy wreath is bringing a dish with grapes. She is followed on the far right by a little girl, who carries an object that is no longer recognizable. On the left a decorated calyx krater has been put on another small table.

On the chous that was discovered later, in Athens, the liknon on the little table is partly covered with a cloth. ${ }^{52}$ It may have contained the mask that is hanging on the structure on the far left of the image, but this is by no means certain. In addition, the mask, shown in profile, is too much damaged to allow us to identify it as a Dionysos mask. To the right of the table stands a bearded man, who, apart from the laurel wreath on his head, wears nothing but a loosely held piece of cloth. With his right hand he seems to offer a youth standing on the left some laurel branches. This young man wears an ivy wreath and is only dressed in a piece of cloth wrapped around his hips, like an artisan. He is shown en face, drinking from a skyphos. His left hand probably takes the proffered branches. On the floor to his left stands a column krater swathed with ivy; more ivy branches can be seen in front of and above the mask. On the far right, a naked boy in a wreath approaches with a large chous. Inscriptions make it clear that the elderly man is called Prometheus, and the youth Epimetheusfigures from mythology with whom the Athenian artisans, who were also allowed to take part in the Anthesteria, would be able to identify. ${ }^{53}$

49 Lezzi-Hafter 1988, 208; Schmidt 2005, 177 ff., who largely agrees with Lezzi-Hafter 1988, dates the ones by the Eretria Painter between 430 and 420, and the one by the Meidias Painter in the following decade. Tzachou-Alexandrí 1997, 480 is of the opinion that the more recently discovered chous is slightly older: $435^{-430}$.

$5^{\circ} \quad$ See above Chapter 6 , notes 80 and 82 .

$51 \quad$ Athens BS 318 (ex Vlasto), from Anavyssos: Addenda 354 (1249.13); BA 216949; FrontisiDucroux 1991, 16o, fig. 97; Lezzi-Hafter 1988, 200 f. and 339, no. 215, pl. 137; Schmidt 2005, 183, fig. 93; Schwarzmaier 2008, 88, fig. 9 .

Athens, 1st ephory 3500 , from a grave discovered underneath the present Pireus Street in Athens: BA 28128 (no image); Tzachou-Alexandrí 1997.

53 Schmidt 2005, 185 f. 
In contrast to the series with the women's ritual around the Dionysos idol, these four images are remarkable for their diversity. This may perhaps be explained from the locations where they were excavated: they were apparently not part of a series for export, but manufactured for the local market. They strike us as snapshots of certain rituals, but are actually aesthetic compositions consisting of combinations of carefully selected motifs: "It was by no means the intention of the vase painters to provide illustrations of the proceedings at the Anthesteria or to document them. Instead, they chose representations that would just remind Athenians of what took place during these large collective festivals in a very general way." ${ }^{\prime 54}$ Nevertheless, they give us a lot of information on these proceedings: that there were events for women and for men; that children of various ages and citizens who made a living as craftsmen and laborers also actively participated in them. This latter category not only identified with Prometheus, but especially with Hephaistos, whom we found on another of the Eretria Painter's choes, riding a mule with his brother Dionysos. ${ }^{55}$ On two of our four choes, as on the stamnoi, Dionysos is present through his mask. ${ }^{56}$ Just his face, even just his eyes can be effective. As Euripides explicitly states in his Bakchai, being in contact with the god Dionysos is to see him and to be seen by him. ${ }^{57}$ On the one hand the empty chair emphasizes his absence, on the other it tells us that his arrival is imminent and anticipated with joy. None of these images depicts some kind of official ceremony: the improvised swing, the baby's chair standing upside down, the little three-legged tables- they all strengthen our impression that this is about activities taking place in a family environment in the context of the Anthesteria. These images clearly illustrate how hard it is to combine our rare literary sources concerning a certain subject—in this case a concrete ritual—with the relevant vase imagery. ${ }^{58}$ In our perspective these choes are evidence of the strong presence of Dionysos in the mental world of the original buyers during the period immediately following the erection of the Parthenon - and not only in the life of the polis, but in the life of every citizen from the days of his childhood. Nevertheless, it is

54 Schmidt 2005, 193: "Die Vasenmaler wollten mit ihren Bildern keineswegs die Vorgänge an den Anthesterien im einzelnen illustrieren oder gar dokumentieren. Sie wählten statt dessen oft Darstellungen, die jeden Athener an die Ereignisse bei den grossen kollektiven Festen im allgemeinen erinnerten."

56 Frontisi-Ducroux 1991, 161.

57 E. Ba. 470.

58 Similarly Schmidt 2005, 180: "Wir müssen vielmehr damit rechnen, dass ein Grossteil der dargestellten Praktiken nie eine schriftliche Erwähnung gefunden hat. Wozu auch? Schliesslich waren die Vorgänge jedermann bekannt, da sie jedes Jahr stattfanden." 


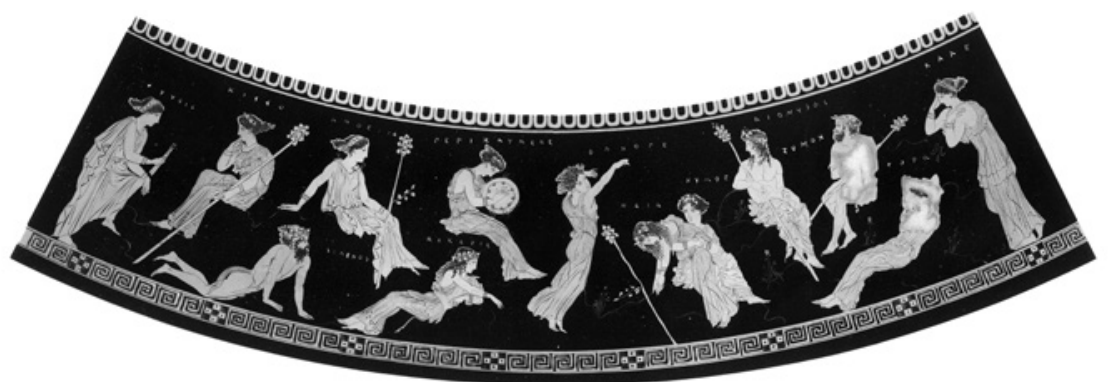

FIGURE 105 Squat lekythos, Eretria Painter, formerly Berlin F 2471 (Furtwängler 1883-87, pl. 55).

striking that in none of the rituals represented the god himself is present-at best there is a mask. This provides a stark contrast with the images of around $440 \mathrm{BC}$ presenting the train with torchlight and music in which the god himself participates, and whose other participants can either be identified as mythical beings or as ordinary humans taking on the roles of nymphs and satyrs in a ritual situation. ${ }^{59}$

Although, as we have seen, the Eretria Painter rarely depicted Dionysos, he was deeply involved in the representation of the god's festivals. This makes his squat lekythos of around 425, which disappeared during the Second World War, all the more important (Figure 105) ${ }^{60}$ Not only was the vase type new at the time-it was also quite innovative as far as composition and choice of subject were concerned. ${ }^{61}$ The god is not represented at floor level, but (like in the work of the Dinos Painter or the Kadmos Painter) has been placed in a hilly landscape. In the company of the women of his thiasos, he watches the whirling dance of one of the younger women. A satyr is sitting next to him, another one is lying in the lower left corner and looks at the scene with great curiosity. One of the maenads, completely exhausted, is hanging in the arms of a companion. Dionysos looks boyish. He wears his long hair loose, his

59 For instance: a pointed amphora by the Achilles Painter, Cab. Méd. 357 (see above Chapter 5, note 20); a stamnos by the Curti Painter, Cambridge (Ma) 1925.30.40: Addenda 320 (1042.1); BA 213538; a bell krater by the Christie Painter, Baltimore 48.74: ARV 1047.11; BA 213580; a bell krater by the Painter of Munich 2335, Louvre G 486: ARV 1163.34; BA 215383.

6o Formerly Berlin F 2471: Addenda 353 (1247.1); BA 216937; Lezzi-Hafter 1988, 226 f. and 342, no. 234, pls. 143d-145; Shapiro 1993, 256, no. 112; Miller/Kästner 2005, 129; SchöneDenkinger 2008, 49 .

61 Lezzi-Hafter 1988, 234-237. 
himation leaves his upper body bare. All figures, including the god, have their names inscribed. ${ }^{62}$ Could this be because the god is represented in an unfamiliar way? The Eretria Painter may have been inspired by the Parthenon's new youthful Dionysos, but presents a version of his own: it is not the athletic body, but the grace of the adolescent that he seeks to emphasize.

Like the Kadmos Painter, the Eretria Painter adapts the outward appearance of Dionysos to the situation, which is rather apt for the god of metamorphoses. This innovative spirit in the handling of Dionysiac imagery is also evident in the work of the Dinos Painter. It is all the more remarkable in view of the fact that the Athenian production of figured pottery diminished sharply after 430 and the whole genre was in a decline. Symptomatic for the situation is the excessive number of anonymous figures in comparison to identifiable ones. This phenomenon is perceptible in the work of all painters. Apart from Eros, Dionysos and his retinue remain well represented, but komos and symposium all but disappear. In the mental world of the beholders of the images Dionysos apparently stills plays an important role, but not in the same way as before $430 \mathrm{BC}$.

Before the 4th century there were still workshops, which produced pieces of a more than average quality that enriched Dionysiac imagery, for instance the workshops of the Meidias Painter and the Pronomos Painter. Compared to the decorators of larger vessels (Beazley speaks of Pot-Painters as opposed to CupPainters) we just discussed, the Meidias Painter and his circle are remarkable for their rather individual selection of vase types: hydriai, some pelikai, loutrophoroi, lebetes, oinochoai. ${ }^{63}$ Especially characteristic is the preference for lekythoi, both normal and squat, and pyxides—kraters only appear incidentally. It is evident, that their clientele is very different form that of, for instance, the Kadmos Painter, which is supported by the provenances of the finds: here, as in the case of the Eretria Painter, Athens and Attica are relatively better represented. These vase types more belong to the household than to the symposium and are used by women rather than citizens.

There is only one representation of Dionysos that can be attributed to the Meidias Painter: a very badly preserved kalpis of about $410 \mathrm{BC}$, which was found at the Kerameikos. ${ }^{64}$ The main image shows a scene in the women's quarters; the frieze of the base has the punishment of Pentheus. Pentheus and a maenad who holds him by the head form the focal point of the main side of the vessel. The standing nude Dionysos, only partly preserved, was placed on the reverse

\footnotetext{
62 From left to right: Silenos, Makaria, Periklymene, Nymphe, and Maia.

63 Boardman 1989, 146; Langner 2013, 152.

64 Athens, Kerameikos 2712: Addenda 362 (1313.6); BA 220498; Schöne 1990.
} 

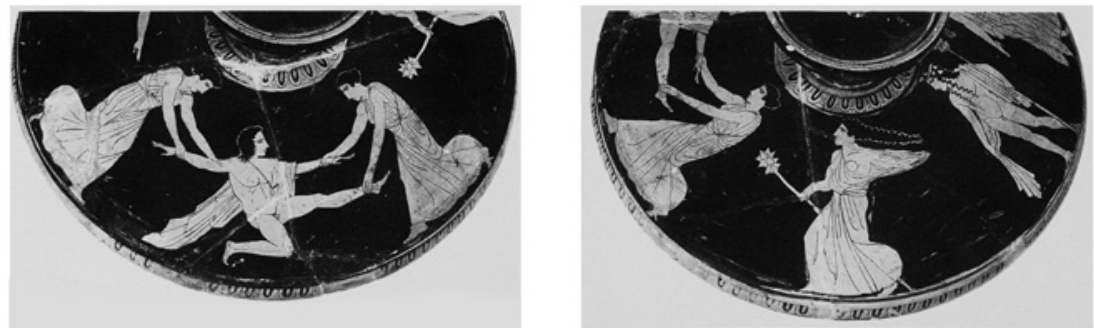

FIGURE 106

Lid of a lekanis, Paris, Louvre G 445, details with Pentheus and Dionysos (Moraw 1998, pl. 23.57).

side in such a way that his thyrsos stands almost precisely underneath the handle. When the reconstitution of the fragments is correct, Dionysos could have watched the punishment of Pentheus for where he stood: a position we also find on a somewhat younger Apulian version of the same event. ${ }^{65}$ In addition, we have a very comparable Dionysos of about one generation earlier who watches the maenads tearing Pentheus apart on an unattributed lekanis from around 440 (Figure 106). ${ }^{66}$

To the right of Dionysos we can see some remains of a small laurel: does this mean Apollo was also depicted? In any case, this Dionysos who invisibly takes his retribution must have looked like a twin brother of the Apollo who, on a volute krater by the Kadmos Painter mentioned earlier, watches Marsyas the musician going towards his gruesome death. ${ }^{67}$ As we have seen in the previous chapter, this resemblance of the two sons of Zeus is far from coincidental: in punishing Pentheus, Dionysos acts in the way Apollo normally acts, as the executor of the order of Zeus. This aspect of Dionysos was not new, but had already been presented in the early 6th century: Dionysos who, on the order of Zeus, addresses Peleus at the occasion of his marriage to Thetis; Dionysos who persuades Hephaistos to liberate the queen of the gods; Dionysos who, with the other Olympians, fights against the giants.

The famous kalpis with the Judgment of Paris of around 400 BC may be attributed to the inner circle of the Meidias Painter. ${ }^{68}$ As in the version by the Kadmos Painter, Paris is represented as an oriental. In the field above him an awe-inspiring Eris seems to rise from a hillock. Themis is absent, however,

65 LIMC VII, Pentheus 16. See in addition Chapter 9, note 16.

66 Louvre G 445. See above Chapter 7, note 42 and below Chapter 9, note 16.

67 See above note 21 .

68 Karlsruhe 259 (B 36): Addenda 362 (1315.1); BA 220515. 


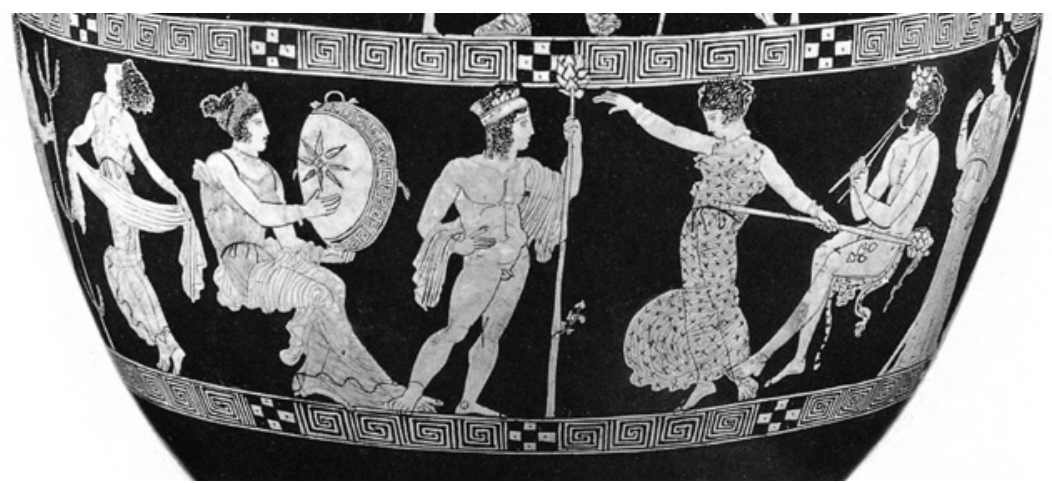

FIGURE 107 Kalpis, follower of the Meidias Painter, Karlsruhe, Badisches Landesmuseum 259 (B 36), detail of the lower frieze (Burn 1987, pl. 39).

which may imply that Eris' actions should not be interpreted as being of significance for the correct progress of world history.

The narrower frieze image of the base shows Dionysos amidst his gracefully dancing bacchantes. He looks very much like the punisher of the lekanis, mentioned earlier, and the kalpis by the Meidias Painter, but the situation seems completely different. Around the god no less than seventeen persons are gathered in a peaceful atmosphere full of music. In the center, to the left of Dionysos, sits a beautiful woman. She beats a richly decorated tympanon placed exactly in line with the head of Eris in the image above. Her rhythms and the tones of the aulos played by a satyr sitting on the far right, accompany a girl in a light, colorfully embroidered chiton, who gracefully spins around her own axis (Figure 107). Two other women dance to the left of the tympanon player: the one on the right is ecstatic, the one on the left appears to be jumping up and down. Between the two we see a small tree: the scene takes place in the open air, as in the lost squat lekythos by the Eretria Painter, the dinos by the Dinos Painter, the cup by Makron, and the Judgment of Paris in the image just above. ${ }^{69} \mathrm{On}$ the far left, below the handle, the only woman wearing an animal skin is looking on. Like the woman watching the dance to the right of the satyr, she holds a thyrsos.

The lower border image on the reverse of the kalpis has a composition with four pairs of women of various ages and status groups. They wear their hair uncovered, in a chignon or pinned up with the help of a decorated headband. They are engaged in friendly conversation, standing or sitting, or with one foot supported by an object—a familiar formula for the representation of a Muse.

$69 \quad$ See above Chapter 5 , note 51 . 
Although here, too, the scene takes place in the open air, the difference between the main side and the reverse is striking: on the one side Dionysiac ecstasy, on the other peaceful companionship. Under the sign of Dionysos, the absence of conflict and tranquil peace are not the same thing. Nevertheless, the whole frieze is permeated with a feeling of harmonious contentment, which stands in stark contrast with the ominous quiet of the Judgment of Paris.

The inner circle of the Meidias Painter also produced a sumptuously decorated pyxis found in Eretria. ${ }^{70}$ The cylindrical part shows women in a feminine interior, and Aphrodite on the verge of mounting her chariot drawn by erotes. At first sight, the image on the lid reminds us of the Eretria Painter's Dionysiac idyll. It shows Dionysos with his thyrsos, his face presented in three-quarter view. Two seated women with lyra and tympanon provide the accompaniment for the whirling dance of five of their companions. Two women each hold the leg of a fawn; they are ready to tear it apart, like Pentheus. The woman to Dionysos' left seems to be addressing him. One of the next two dancers holds a thyrsos, while the other carries a frightened child over her shoulder, just holding it by one of its little legs. Will the child be torn apart, like the fawn?

Although no actual horrors are depicted, a gruesome event of this kind seems rather unsuitable for a pyxis; the image is unique. In the second half of the $5^{\text {th }}$ century, the pyxides repertoire is dominated by Eros and images of a peaceful female world with appropriate requisites such as boxes, baskets and mirror. Heroes such as Herakles hardly ever occur, and Hermes and Aphrodite are the most frequently depicted gods. Once in a while one finds satyrs and their dancing female partners. ${ }^{71}$ In any case, the contrast between the lid and the 'box' is striking: does this perhaps refer to the two extremes of female life? As we will see, a similar contrast may be found in the decoration of the bronze Derveni krater. ${ }^{72}$

The 'box' of another, similar pyxis has a decoration of laurel branches; its lid presents an idyllic image. ${ }^{73}$ Two erotes are kneeling on either side of the image. They each have a fillet in their hands. Between them we see Ariadne with a mirror and a youthful naked Dionysos with his thyrsos. They sit closely together, but are facing away from each other. This is a simplified version of

$70 \quad$ London E 775 (1893.11-3.2): Addenda 364 (1328.92); BA 220648; Burn 1987, 34 and 79 f., pl. 18 a-c, pl. 19 a; Grassigli 1999, 112, fig. 16.

71 Collection unknown: BA 8904 (no image: satyr pursuing a maenad); in the art trade: BA 9021718 (no image: maenad and anonymous figures); Sarajevo 34: BA 9495 (seated satyr). Concerning pyxides imagery see in addition Schmidt 2005, 119-151.

72 See below Chapter 9 .

73 Karlsruhe 296 (B 1873): Addenda 364 (1328.95); вA 220651. 
the so-called pyramid composition that was popular during the 4th century and continued in use until Imperial times. ${ }^{74}$ The remaining space is taken up by a seated naked youth who is approached by a young woman carrying a large plemochoe, a vessel used for ointments. Divine and human wedding are juxtaposed: a highly appropriate motif for a vase that was frequently given as a token of love or a wedding present. ${ }^{75}$

An artistically modest, but stylistically similar kalpis seems to introduce the Dionysiac imagery of the 4 th century. ${ }^{76}$ In the center of the image we see a seated Dionysos, youthful and with long flowing locks. He sits in a relaxed attitude as in the east pediment of the Parthenon, and has the thyrsos on his left arm. He looks back towards an unidentified young woman approaching from the right. Between the two a small panther is reaching for her hand. A satyr with a thyrsos appears to have been waiting for her. Aphrodite is seated above on the left, Hermes above right. An eros is hovering above Dionysos, another one is approaching Hermes. Below on the right a seated nymph is looking at the scene. Some flowers and an ivy branch in the field between the figures indicate an open-air situation. Is the nameless woman Ariadne, or is this a mortal woman play-acting? Did she come for Dionysos or for the satyr?

An exquisite cup fragment from Kerch on the Black See is another forerunner of the 4th century. It shows an, unfortunately incomplete, Dionysos riding a large panther, which is cheerfully stepping along. ${ }^{77}$ Instead of his kantharos, he holds the horn of plenty; his thyrsos is decorated with an embroidered bow. We already encountered Dionysos riding a panther on the kalpis from Pella, in a very special mythological context inspired by the west pediment of the Parthenon. ${ }^{78}$ Like several other Dionysos figures just discussed, the god wearing elegant lace-up boots on a fine squat lekythos from Corinth seems to have been inspired by the east pediment of the Parthenon. ${ }^{79}$

This brings us to the Pronomos Painter, a brilliant vase painter of around $400 \mathrm{BC}$; only a few of his works are known. His name is derived from the famous and often-discussed volute krater from Ruvo (Figure 108). ${ }^{80}$ Its best-known

\footnotetext{
74 Gasparri 1986, 509.

75 Schmidt 2005, 150.

76 Cambridge (Ma) 1960.347: Addenda 367 (1341.2); BA 217539 (apparently identical with BA 1012159, Braunschweig, A. Loebbecke).

77 St. Petersburg 1867.68.953: ARV 1329.117; BA 220672; Burn 1987, 8 o.

78 See above Chapter 7 , note 88.

79 London E 703: Addenda 365 (1330.9); BA 220684.

$80 \quad$ Naples H 3240: Addenda 365 (1336.1); BA 217500; Paul-Zinserling 1994, 44; Lissarrague 2010, and $2013,30-32$, fig. 7 .
} 

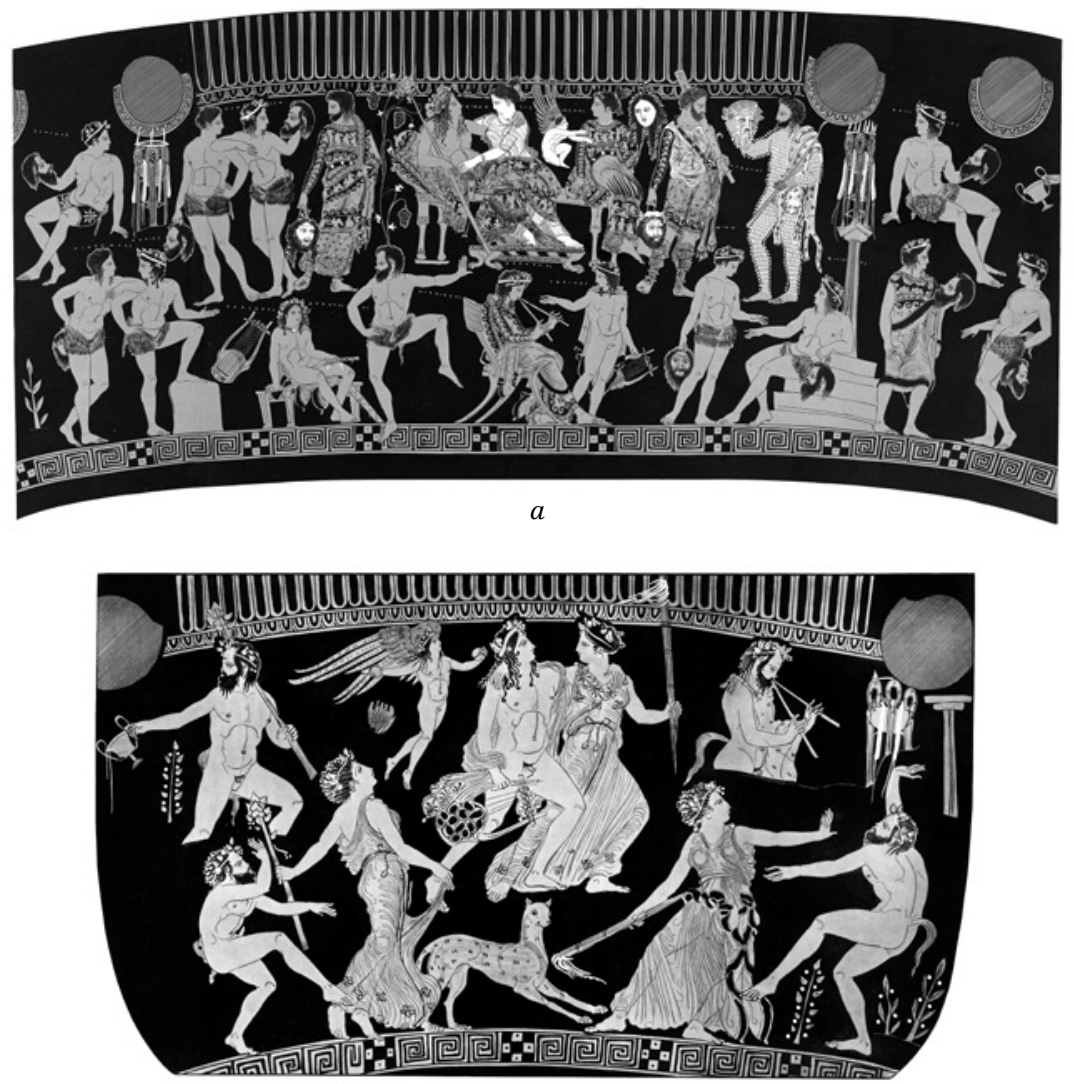

$b$

FIgU Re 108 Volute krater, Pronomos Painter, Naples, Museo Archeologico Nazionale H 3240.

a. side A (FR pl. 143-4).

b. side $B$ (FR pl. 145).

side shows the young Dionysos, his lower body covered by a rich himation, watching from his bed a performance by a large group of actors, in the company of Ariadne who holds him tenderly. As Claude Calame convincingly demonstrates, the image is an idealized representation of a celebratory ritual in honor of the liberator Dionysos Eleuthereus. ${ }^{81}$ This celebration of the victory in the dramatic contest was the high point of the series of theatrical performances which took place on the occasion of Anthesteria; the closing performance was

81 Calame 2010, 70: “... Dionysos Eleuthereus, Liberator of men who are free, coming from Eleutherai (Sophokles TrGFr. 172 Radt)." 
a satyr play. ${ }^{82}$ The image on the reverse side is closely linked to that on the main side, but, on the other hand, takes us from the ritual to the mythical level. It shows a naked Dionysos, with a lyra in his hand, and Ariadne, carrying a torch, moving euphorically towards the right in close embrace. To the left of Dionysos, Eros, cymbals in his hands, comes flying to escort them. On each side of the pair a satyr is moving in the same direction, in both cases partly hidden by an elevation in the landscape. The one in front plays the aulos, the one in the rear, carrying thyrsos and kantharos, looks back towards the scene on the other side of the vase. Below, on the left as well as on the right, we see a female dancer and a satyr, who appear to act out the titillation of their relationship in a mimic dance. One of the women is holding a thyrsos, the other a lighted torch. The latter seems to keep in check the panther which appears between the two pairs, its head shown in three-quarter view. Where is the divine couple going?

A more or less contemporaneous lekanis from Spina, stylistically more similar to the Meidias Painter, likewise seems to leave this question deliberately unanswered. ${ }^{83}$ It roughly shows the same motif, but here it is Ariadne who carries the lyra and leads the way. The aim is, apparently, the blissful unknownthe future promised to the Bacchic initiates in the famous gold tablets that accompanied them in death. ${ }^{84}$

A sumptuous calyx krater showing the stylistic influence of the Pronomos Painter presents Dionysos surrounded by women and satyrs in a paradisiacal ambiance very similar to that of the Dinos Painter's calyx krater of a few years earlier; the god's pose is almost identical (Figure 109). ${ }^{85}$ Here the god is flanked by two erotes; the women do not seem to be engaged in the ritual presentation of gifts, the accompanying podium is also lacking. One of the women lifts a bunch of grapes; bunches of grapes can also be seen in the surrounding landscape. There is no panther, however; in the foreground a woman is playing with a hare. The god looks into the distance, and sees neither the women, nor the beholder of the vase. The image gives the impression of an apotheosis of Dionysos in a permanent state of bliss. The contrast with the scene depicted on the reverse is therefore rather forceful. Two dancing satyrs are blocking the way of a woman swinging a thyrsos, who is briskly moving towards the

82 Calame 2010, 71-78. The vase itself may have been an agalma for Dionysos and Ariadne on the occasion of a victory in a dramatic contest and, in fact, have been part of a ritual.

83 Ferrara 5388: BA 19154.

84 Calame 2008, 161.

85 Madrid 11011: Addenda 366 (1336.1 below); BA 217505; Paul-Zinserling 1994, 44 f.; Moraw 1998, 300, no. 469, pl. 24 fig. 59 a-b. 


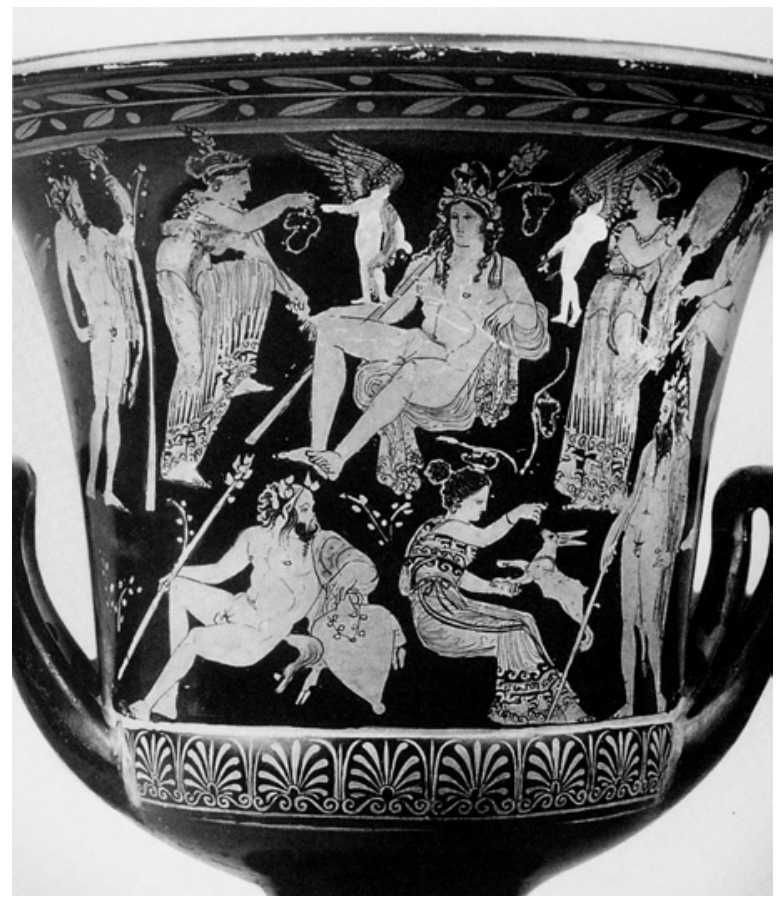

FIGURE 109

Calyx krater, circle of the Pronomos Painter, Madrid, Museo Arqueológico Nacional 11011, side A (cva Madrid 2, pl. 10.2).

right. Above left and right another satyr and a Dionsyiac woman are watching the scene.

As far as the Dionysiac repertoire of the vase painters active just after 430 is concerned, we find that the work of the Pronomos Painter and his milieu confirms the striking changes: the triumph of the new, youthful Dionysos, his idyllic existence-blissful, erotically tinted-in a distant world. ${ }^{86}$ The bearded Dionysos and his accompanying thiasos only appear in representations of the return of Hephaistos - a myth that apparently remained topical. ${ }^{87}$ A unique depiction of Silenos being captured by a group of Orientals looks like a scene

86 In this context it is significant that Eros is increasingly part of the Dionysiac retinue, compare Paul-Zinserling 1994, $5^{2}$ f.

87 Pelike Munich S 68: Para 482 (1347.1); BA 217593; calyx krater Agrigento C 1581: Para 482 (1347); вА 217595 . 
from a play. ${ }^{88}$ The disappearance of the bearded god also meant the ritual procession disappeared from the repertoire; the figures who participated in it now engage in various activities - music or the preparation of sacrificial gifts, for instance - in the idyllic surrounding landscape. Their identities are no longer ambivalent: the satyrs cannot be taken for citizens or for the actors from the satyr play, the women do not belong to the human world.

All of this is borne out by the names that are now increasingly given. This brings us to the issue of 'personification'. Scholars still use this term to refer to abstract concepts turned into mythological personages by poets and artists. These are said to have particularly occurred during the late $5^{\text {th }}$ century $\mathrm{BC}$, and mostly in images with an Aphrodisiac or Dionysiac theme- to remain with Dionysos, for instance Eirene, Makaria, Eudaimonia, etc. The origins and derivations of these 'personifications', however, are often far from clear. ${ }^{89}$ In addition, inadequate modern projections concerning the very different way of thinking of the ancient world are, as B. Borg has shown, not very helpful. ${ }^{90}$ It seems more useful to investigate in what way the inscription of names changed the Dionysiac thiasos-what it was that the vase painters wanted to refer to. What immediately strikes us is that Dionysos' retinue is less and less presented as a group of anonymous figures engaged in the same actions. Whether they carry a mythological name or a name that to the modern beholder seems rather like an abstract concept: every woman and every satyr around Dionysos becomes an individual. Moreover, the names of these individuals characterize the god's world: it is a world of peace (Eirene), a world of good fortune and material wellbeing (Eudaimonia), a world where life ends with a happy death (Makaria). ${ }^{91}$

88 Munich 67: Addenda 368 (1347.2); BA 217594. Dionysos on the stage will be discussed in the next chapter.

89 Gemelli Marciano 2013, 56; compare earlier Isler-Kerényi 1969, $7 \mathrm{f}$.

90 Borg 2002, 80: "So ist uns in vielen Fällen jede Möglichkeit genommen, sicher zu entscheiden, ob ein Wesen als göttliche Macht oder als auf Abstraktion beruhende Fiktion geschaffen oder generell rezipiert wurde" and in conclusion p. 233: "Dies bedeutet..., dass es letztlich nicht nur unmöglich ist, (bestimmte) Personifikationen von göttlichen Wesen grundsätzlich zu unterscheiden, auch nicht nur unnötig, sondern nicht einmal wünschenswert, denn gerade diese 'Schnittstelle' zum Göttlichen, die grundsätzlich alle Personifikationen besitzen, ist ebenso Ausdruck wie Ursache der Lebhaftigkeit des Eindrucks, den die Darstellungen vermitteln."

91 Compare Smith 2011, 78 f. (Eirene); Shapiro 1993, 62 (Eudaimonia). The figure named Hebe on the volute krater by the Kadmos Painter in Ruvo (see above p. 191 fig. 102), for instance, evokes the daughter of Hera and Herakles' bride on the Olympus-post-mortal conjugal bliss as a reward for a life of suffering; Shapiro 1993, 171. 
Vase painting after 430 вс does not only show a significant change in the outward appearance of the god; his relationship with the figures that surround him and the environment in which he is shown, have also changed completely. No longer do we find individual participants addressing the beholders and engaging them. These, in their turn, can no longer identify with the figures, but look at the scene as if it takes place on a stage. In addition, this 'stage' and the polis are not interchangeable; the scene rather refers to a blissful counter world. Both the deified Semele of the Kadmos Painter's volute krater in Ruvo and Makaria on the lost squat lekythos by the Eretria Painter make it clear that the scene is set in the future-the future that is in store for the Bacchic initiates. ${ }^{92}$ As is evident from Euripides Bakchai, which had its premiere in the final years of the $5^{\text {th }}$ century, Dionysos is still very well able to interfere in the life of the community. The vase painters, however, are no longer concerned with a god who acts for the rightful order, but with one who embodies the hope of admission to a joyful counter world.

92 For Semele as a prototype of a female initiate, see Isler-Kerényi 2007, 168-170. 